\title{
Correction to: Disruption of hypoxia- inducible fatty acid binding protein 7 induces beige fat-like differentiation and thermogenesis in breast cancer cells
}

Masahiro Kawashima ${ }^{1,5^{*}}$, Karim Bensaad ${ }^{1}$, Christos E. Zois ${ }^{1}$, Alessandro Barberis ${ }^{2}$, Esther Bridges ${ }^{1}$, Simon Wigfield ${ }^{1}$, Christoffer Lagerholm³ ${ }^{3}$ Ruslan I. Dmitriev ${ }^{4,6}$, Mariko Tokiwa ${ }^{5}$, Masakazu Toi ${ }^{5}$, Dmitri B. Papkovsky ${ }^{4}$,

Francesca M. Buffa ${ }^{2}$ and Adrian L. Harris ${ }^{1}$

\section{Correction to: Cancer Metab 8, 13 (2020) \\ https://doi.org/10.1186/s40170-020-00219-4}

Following publication of the original article [1], the authors identified an error in Fig. 7. The correct figure is given below.

\section{Author details}

'Department of Oncology, Molecular Oncology Laboratories, Weatherall Institute of Molecular Medicine, University of Oxford, John Radcliffe Hospital, Oxford OX3 9DS, UK. ${ }^{2}$ Department of Oncology, Computational Biology and Integrative Genomics Lab, CRUK/MRC Institute for Radiation Oncology, University of Oxford, Old Road Campus Research Building, Roosvelt Drive, Oxford OX3 7DQ, UK. ${ }^{3}$ Wolfson Imaging Centre, Weatherall Institute of Molecular Medicine, University of Oxford, John Radcliffe Hospital, Oxford OX3 9DS, UK. ${ }^{4}$ School of Biochemistry and Cell Biology, University College Cork, Cavanagh Pharmacy Building, 1.28, College Road, Cork, Ireland. ${ }^{5}$ Department of Breast Surgery, Graduate School of Medicine, Kyoto University, 54 Shogoin-Kawahara-cho, Sakyo-ku, Kyoto 606 8507, Japan. ${ }^{6}$ Institute for Regenerative Medicine, I.M. Sechenov First Moscow State University,

Moscow, Russian Federation.

Published online: 10 August 2020

\section{Reference}

1. Kawashima M, Bensaad K, Zois CE, et al. Disruption of hypoxia-inducible fatty acid binding protein 7 induces beige fat-like differentiation and

The original article can be found online at https://doi.org/10.1186/s40170020-00219-4.

* Correspondence: masa0123@kuhp.kyoto-u.ac.jp

'Department of Oncology, Molecular Oncology Laboratories, Weatherall Institute of Molecular Medicine, University of Oxford, John Radcliffe Hospital, Oxford OX3 9DS, UK

${ }^{5}$ Department of Breast Surgery, Graduate School of Medicine, Kyoto University, 54 Shogoin-Kawahara-cho, Sakyo-ku, Kyoto 606 8507, Japan Full list of author information is available at the end of the article thermogenesis in breast cancer cells. Cancer Metab. 2020;8:13 https://doi. org/10.1186/s40170-020-00219-4.

(c) The Author(s). 2020 Open Access This article is licensed under a Creative Commons Attribution 4.0 International License, which permits use, sharing, adaptation, distribution and reproduction in any medium or format, as long as you give appropriate credit to the original author(s) and the source, provide a link to the Creative Commons licence, and indicate if changes were made. The images or other third party material in this article are included in the article's Creative Commons licence, unless indicated otherwise in a credit line to the material. If material is not included in the article's Creative Commons licence and your intended use is not permitted by statutory regulation or exceeds the permitted use, you will need to obtain permission directly from the copyright holder. To view a copy of this licence, visit http://creativecommons.org/licenses/by/4.0/. The Creative Commons Public Domain Dedication waiver (http://creativecommons.org/publicdomain/zero/1.0/) applies to the data made available in this article, unless otherwise stated in a credit line to the data. 
a
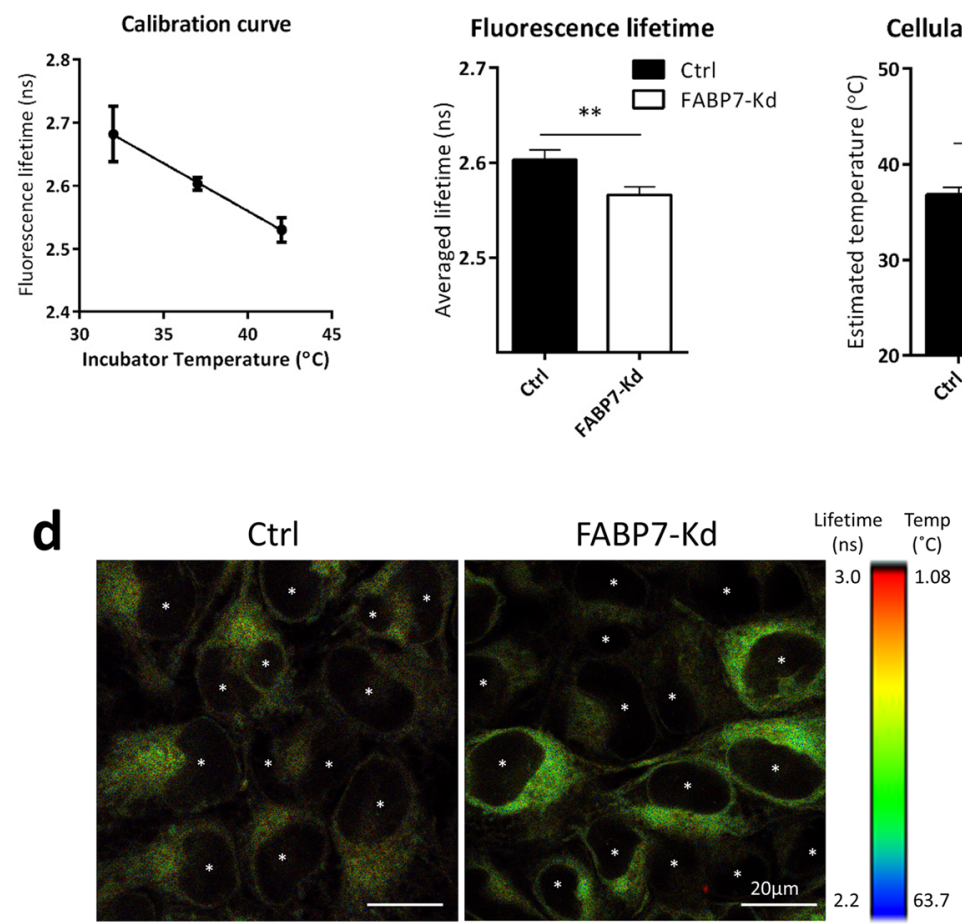

Fig. 7 FABP7 knockdown (FABP7-Kd) increased cellular temperature. a Calibration curve of T probe generated using control cells (Ctrl). $X$ and y axes show incubator temperatures and average fluorescence lifetime, respectively. b Average fluorescence lifetimes of Ctrl and FABP7-Kd. C Calculated cellular temperature of $\mathrm{Ctrl}\left(37^{\circ} \mathrm{C}\right)$ and FABP7-Kd. d Representative images of fluorescence lifetime imaging microscopy. Color scale indicates estimated temperature. Scale bars; $20 \mu \mathrm{m}$. Asterisks indicate nuclei locations. Error bars, SD; ${ }^{* *} p<0.01, n=3$ 